\title{
Sustainability of the fiscal imbalance and public debt under fiscal policy asymmetries in Sri Lanka
}

\author{
Anuruddhi Shanika K Rathnayake \\ Crawford School of Public Policy, Australian National University, WEH Stanner Building, Room 1.34, 132 Lennox Crossing, Acton 0200, \\ Australia
}

\section{A R T I C L E I N F O}

\section{Article history:}

Received 19 May 2019

Received in revised form 30 October 2019

Accepted 2 December 2019

Available online 4 December 2019

\section{JEL classification:}

E62

F34

$\mathrm{H} 50$

H60

H62

H63

\section{Keywords:}

Sustainability of public debt

Fiscal reaction function

Policy asymmetries

Sri Lanka

\begin{abstract}
A B S T R A C T
This paper investigates the sustainability of Sri Lanka's fiscal imbalance and public debt. To test for sustainability of the fiscal imbalance, the study applies a symmetric ARDL (autoregressive distributive lag) technique to estimate a government intertemporal budget constraint. And to test for sustainability of public debt, it applies an asymmetric ARDL technique to estimate a fiscal reaction function, which allows for differential responses in the primary budget balance depending on whether shocks to regressors are positive or negative. Annual data for the period 1961-2018 are used in the estimations. The results indicate that Sri Lanka's fiscal management is inconsistent with strong form sustainability, which requires that expenditures not grow faster than revenues. However, estimation of the fiscal reaction function finds robust evidence for fiscal policy asymmetries. Evidence emerges that Sri Lanka's fiscal policy stance is procyclical with strong stabilization tendencies in economic expansions that are not sustained in contractions. Against upsurges in the debt-to-GDP ratio, authorities are found to pursue fiscal consolidation, thus suggesting weak form sustainability.
\end{abstract}

(c) 2019 Elsevier Inc. All rights reserved.

\section{Introduction}

The sustainability of fiscal policy is at the forefront of policy concerns in Sri Lanka, fueled by the ever expanding budget deficit and a growing burden of public debt and debt service. Among emerging economies, Sri Lanka has the largest ratio of gross financing requirements to GDP (International Monetary Fund (IMF), 2018). Over the last three decades, Sri Lanka's debt-to-GDP ratio was generally over 70 percent. Nevertheless, Sri Lanka has never defaulted on servicing its debt. Though there is no welldefined optimal ratio of debt-to-GDP, $60 \%$ is commonly taken as a threshold. Government debt service consistently appears as the biggest item in Sri Lanka's budget, outstripping defense spending to claim over $80 \%$ of government revenue. Khatri, Ginting, and Athukorala (2017) show that Sri Lanka has an unusual fiscal situation for a fast-growing emerging market with a secular weakening in revenue to GDP, which has reached a very low level by world standards.

The consensus is that Sri Lanka is in a debt trap and preserving the sustainability of public debt ${ }^{1}$ has become an elusive goal for the country. IMF (2018) showed that the risk of unsustainability of Sri Lanka's public debt has evolved in relation to

E-mail addresses: shanika.rathnayake@anu.edu.au, ashanika.rathnayake@gmail.com (A.S.K. Rathnayake).

1 IMF (2002) referred to the sustainability of public debt as a country's ability to service its borrowings without compromising its long-run development targets, rescheduling debt service, or accumulating arrears. Borrowings include external and domestic, short-term and long-term, and public, publicly guaranteed, and private non-guaranteed debt. 
exchange rate risk and rollover risk, but that its foreign debt remains sustainable. Jubilee Debt Campaign (2015) revealed that Sri Lanka is at risk of default with the potential for debt crises due to its high debt-to-GDP ratio and heavy external debt payments. To avert imminent financial distress, Sri Lanka has been utilizing the extended fund facility of the International Monetary Fund with austerity conditions imposed. As evidenced in financial crises elsewhere in the developing world, high debt levels can create unfavorable cycles of rising borrowing costs and growing fiscal imbalances that are severely disruptive to macroeconomic management.

With the ultimate objective to preserve fiscal sustainability, Sri Lanka has attempted to improve the primary fiscal balance and reduce its debt stock, ${ }^{2}$ largely through debt restructuring and rules-bound fiscal consolidation policies under its Fiscal Management (Responsibility) Act. ${ }^{3}$ Further, the Active Liability Management Act (ALMA) No. 8 of 2018 was enacted to improve public debt management. However, the IMF expressed concern about stalled fiscal consolidation and the likelihood of missing the targeted deficit-to-GDP ratio given envisioned revenue growth which appears insufficient to cover increases in recurrent expenditures and investment spending plans (International Monetary Fund (IMF), 2015; 2018). Despite the consolidation attempts, gross financing requirements and the public debt stock of the Sri Lankan government have been ever increasing. This situation leaves ambiguity over the sustainability of fiscal imbalances and public debt. Why fiscal consolidation attempts have failed to narrow the deficit and bring down the debt level is thus in need of scrutiny.

Against this backdrop, this paper examines three research questions in the Sri Lankan context: (i) Is the fiscal imbalance sustainable? (ii) Is the public debt sustainable? (iii) How can fiscal measures be implemented to achieve the sustainability of public debt? To answer these questions the study applies the government intertemporal budget constraint (IBC) and Bohn (1998) test of fiscal sustainability with reference to a fiscal reaction function (FRF), adopting an autoregressive distributed lag (ARDL) estimation approach. As per Bohn's test, a reaction function that improves the primary balance in response to an increase in the debt-to-GDP ratio provides a sufficient condition for the sustainability of the fiscal balance. Compliance with this sustainability condition becomes challenging during economic downturns or periods of liquidity constraint, however, which tends to result in asymmetries in policy implementation. To allow for such asymmetries, this study enriches the FRF framework by allowing for nonlinearity in the policy response.

Departing from the extant literature, in this paper the asymmetry is introduced by including positive and negative partial sum decompositions of the regressors of the FRF. This distinctive identification procedure stems from the contribution of Shin, Yu, and Greenwood-Nimmo (2014) to nonlinear ARDL (NARDL) analysis. The asymmetric modelling approach allows for differential treatment of model dynamics in two respects: (i) time-varying responsiveness of fiscal adjustments to upturns and downturns in the debt-to-GDP ratio and the business cycle; and (ii) short-run versus long-run behavior of the variables embodied in the FRF. The paper shows that under a linear specification of the FRF, the estimations are flawed and inferences are inconclusive. This is because Sri Lanka's fiscal authorities have in reality been implementing fiscal consolidation measures in an asymmetric way in response to ever-increasing debt levels. In essence, the approach of this paper allows for greater nuance in characterizing the behavior of the fiscal authorities in their efforts to avert an ever increasing debt-to-GDP ratio. This is the novel contribution of the paper to the literature on the sustainability of public debt in an emerging economy.

The remainder of the paper is structured into four sections. The next section presents a brief survey of the literature on the sustainability of fiscal policy around the world. Section 3 discusses the theoretical framework and the data employed to investigate the research questions, and also develops the empirical approach used in the estimation procedure. Section 4 presents the empirical findings. The final section concludes the paper with a few policy lessons for achieving fiscal sustainability in Sri Lanka.

\section{Literature review}

The extant literature offers an array of tools to analyze the sustainability of fiscal policy in terms of the fiscal imbalance and public debt. These tools are multifaceted and very sensitive to the assumptions involved. The basic requirement for sustainability of the fiscal imbalance is that a government stays within the IBC, which captures a stable long-run association between government revenue and expenditure as follows:

$$
\mathrm{Gx}_{\mathrm{t}}+\left(1+\mathrm{r}_{\mathrm{t}}\right) \mathrm{D}_{\mathrm{t}-1}=\mathrm{R}_{\mathrm{t}}+\mathrm{D}_{\mathrm{t}}
$$

where $\mathrm{Gx}_{\mathrm{t}}$ stands for government expenditure, excluding interest payments on public debt; $r_{t}$ is the real interest rate; $R_{t}$ is government revenue; and $D_{t}$ is the government debt level. Similar equations can be specified for periods $t+1$, $t+2$, and so on . Recursive iteration via forward substitution yields the rearranged IBC given below:

$$
\mathrm{D}_{0}=\sum_{\mathrm{t}=1}^{\infty} \delta_{\mathrm{t}}\left(\mathrm{R}_{\mathrm{t}}-\mathrm{Gx}_{\mathrm{t}}\right)+\lim _{\mathrm{n} \rightarrow \infty} \delta_{\mathrm{n}} \mathrm{D}_{\mathrm{n}}
$$

\footnotetext{
${ }^{2}$ A country with high debt levels requires adequate primary surpluses for a prolonged period to stabilize its debt-to-GDP ratio and move that ratio to a sustainable path toward a benchmark value (IIMF, 2013).

${ }^{3}$ The Fiscal Management (Responsibility) Act, No. 3 of 2003 sets forth objectives to institutionalize financial discipline, reduce the fiscal deficit, and improve public funds management so as to achieve debt sustainability.
} 
where $\delta_{t}=\prod_{s=1}^{t} 1 /\left(1+r_{s}\right)$ is the discount factor. Eq. (2) states that the debt level in time $t=0$ is the present value of expected future primary balances plus a limit value for government debt as time goes to infinity. As per Eq. (2), fiscal policy is

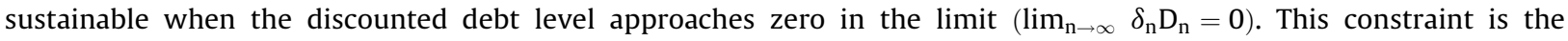
transversality condition that rules out 'Ponzi financing'. Ponzi financing occurs when the principal and interest payments on existing debt are serviced by issuance of new debt on a continuing basis. Provided the prohibition on Ponzi financing holds, the public debt remains lower than the discounted future primary surpluses. The fiscal balance is considered to be sustainable if and only if the debt stock rises more slowly than the real interest rate, which is taken as a proxy for economic growth (Baharumshah \& Lau, 2007). Conceptually, the sustainability of fiscal imbalances is easily specified free of ambiguity. Yet the principle is hard to apply in practice. ${ }^{4}$ Nevertheless, satisfying Eq. (2) is regarded as the basic requirement for fiscal sustainability.

The sustainability of public debt is conventionally ascertained by means of time series properties of debt and/or deficit series and tests for cointegration among the components of the IBC. The stationarity test examines the mean-reverting property of debt and/or deficit series which rests on the response of the fiscal stance to fluctuations in debt following a shock. An appropriate response in fiscal stance can ensure debt levels meet the terms of the transversality condition for sustainability. Formally, debt is on an explosive path and regarded as unsustainable when the debt-to-GDP ratio has a unit root (Jha et al., 2012).

The conventional tests for stationarity are performed with observed time series on the premise that history is a reliable guide to the future. However, important aspects of historical debt dynamics could be missed if structural breaks are ignored. A variety of statistical procedures have been applied to mitigate this problem. Hakkio and Rush (1991) and Quintos (1995) found cointegration between government expenditure and revenue in data once they identified structural breaks associated with regime changes. Jha and Sharma (2004) showed how the public debt of India may appear sustainable once regime shifts are taken into account allowing cointegration among government revenue and expenditure to be discerned. Camarero, Carrion-i-Silvestre, and Tamarit (2015) allowed for multiple structural breaks and multi-cointegration turns in a stock-flow approach to find in favor of weak fiscal sustainability for 17 OECD countries. Chen (2016) used a quantile cointegration approach to find strong evidence of quantile-dependent cointegration of government spending and revenue in the US.

However, although tests for unit roots and cointegration are widely used, these tests suffer from inherent weaknesses and provide no definitive evidence of fiscal sustainability in a stochastic environment (Bohn, 1995). Bohn (2007) argued that a debt stock integrated of any order may indeed be sustainable in that the IBC condition can be fulfilled even in the absence of cointegration among fiscal variables that are non-stationary. Therefore, Bohn (2005) identified that tests for unit roots and cointegration are an ad-hoc approach to assess sustainability.

The literature on fiscal sustainability gained momentum with Bohn's (1998) model-based test of sustainability using an FRF (Bohn's FRF). Bohn's FRF specifies a fiscal policy feedback rule, which involves the response of the primary balance to the debt-to-GDP ratio, to determine a sufficient condition for sustainability of fiscal policy. The FRF takes the following form:

$$
\mathrm{ps}_{\mathrm{t}}=\rho \mathrm{d}_{\mathrm{t}}+\alpha \mathrm{Z}_{\mathrm{t}}+\varepsilon_{\mathrm{t}}
$$

where $\mathrm{ps}_{\mathrm{t}}$ is the primary surplus; $\mathrm{d}_{\mathrm{t}}$ is the debt-to-GDP ratio; $\mathrm{Z}_{\mathrm{t}}$ is a set of determinants of the primary surplus; and $\varepsilon_{\mathrm{t}}$ is the disturbance term. In recent studies, the contemporaneous debt-to-GDP ratio is replaced with its lagged value as debt is often serviced in the next period. The determinants of the primary balance are mainly measures of government expenditure and the business cycle. Bohn (1995) observed that this model fit US data fairly well and determined that US fiscal policy was sustainable.

The literature on fiscal sustainability using Bohn's FRF has expanded rapidly. Models of fiscal policy and debt stabilization behavior vary in line with government policy objectives and macroeconomic conditions. Owing to asymmetry in the fiscal policy response to macroeconomic conditions, the assumption of linearity in FRF dynamics is often relaxed with alternative specifications. Polynomial functional forms in terms of cubic and quadratic specifications are commonly adopted to characterize the response of the primary balance to debt levels. Bohn's (1998) quadratic and cubic specifications of the FRF showed that the marginal response of the primary balance increases with higher debt-to-GDP ratios. Abiad and Baig (2005) and Celasun, Debrun, and Ostry (2006) used spline regression, with a threshold set at a debt-to-GDP ratio of 50\%, to allow for a kinked relationship between fiscal effort and debt level. Their finding was that fiscal effort rose with the debt level, but tapered off when the debt was beyond the threshold. In contrast, Mendoza and Ostry (2008) found that fiscal responsiveness to debt was much stronger for advanced economies, and more so when debt was beyond the threshold. Ghosh, Kim, Mendoza, Ostry, and Qureshi (2013) found that in advanced economies the primary balance responded asymmetrically to lagged debt, remaining positive at moderate debt levels but weakening when debt levels rose above 90-100\% of GDP. Checherita-Westphal and Ždarek (2017) observed that the positive response of the primary surplus to higher debt levels in euro countries strengthened during the debt crisis. Overall, the evidence yields no consensus regarding a stronger fiscal response at higher debt levels.

\footnotetext{
${ }^{4}$ The sustainability condition indicated in Eq. (2) is difficult to apply in practice on two grounds. First, since the sustainability condition holds for an infinite time horizon, large future primary surpluses could in principle cover a large current deficit. Second, no constraints are placed on the relationship between future revenue and spending. For detailed discussion see Jha et al. (2012, p. 22).
} 
Another aspect of asymmetry in fiscal policy is captured by a regime-switching specification in Bohn's FRF, which allows for shifts in fiscal policy in accordance with political preferences. As per Leeper (1991), fiscal regimes are treated as being of two types, 'passive' and 'active'. In response to increasing debt, a higher primary surplus is generated during 'passive' fiscal regimes, while under 'active' regimes there is a lack of motivation to stabilize debt and consequently price levels are assumed to rise. Using a Markov switching framework, Afonso and Toffano (2013) observed clear evidence of active and passive regimes in the UK, with the active regime predominating. Ricci-Risquete, Ramajo, and De Castro (2016) showed that Spain had a passive fiscal policy with persistent commitment to meet the Maastricht criteria and the Stability and Growth Pact rules, whereas the euro-area had a passive fiscal policy only some of the time. Aldama and Creel's (2017) regime-switching model showed strong evidence for sustainability in US fiscal policy despite persistent unsustainable fiscal regimes.

Empirical studies on the sustainability of fiscal policy of Sri Lanka are limited ${ }^{5}$ and often highlight deterioration in the sustainability of public debt and fiscal policy. Behuria (2018) argued that Sri Lanka was trapped in debt of its own making, having made massive infrastructure investments to boost the economy. As per the IMF (2018), downside risks, which include risk from contingent liabilities, have remained considerable. Stress tests indicate high risk to the sustainability of public debt in Sri Lanka (International Monetary Fund (IMF), 2018). Chua, Perera, and Suardi (2018) followed Aldama and Creel (2017) in applying a regime-switching model and were skeptical about the long-term sustainability of Sri Lanka's fiscal policy, although the fiscal policy ruled out Ponzi financing during the period 1961-2017.

The regime-switching models offer an appealing feature in capturing asymmetry in fiscal policy, yet these models fail to accommodate differences in asymmetry between the short run and the long run. This paper overcomes this limitation by allowing for asymmetric cointegration of non-stationary fiscal variables that is time varying. This is achieved through the specification of positive and negative partial sum decompositions of the regressors of Bohn's FRF.

\section{Theoretical framework and data}

\subsection{Theoretical framework}

This section presents two models to be employed in this study. Model 1 pertains to the sustainability of the fiscal imbalance within the framework of the intertemporal budget constraint. Model 2 pertains to the sustainability of the public debt within the framework of Bohn's fiscal reaction function.

\subsubsection{Model 1: Sustainability of the fiscal imbalance}

Model 1 is in the class of ad-hoc tests of sustainability and starts with the IBC. Following Hamilton and Flavin (1986) and Baharumshah and Lau (2007), Eq. (2) may be transformed to yield:

$$
\mathrm{G}_{\mathrm{t}}-\mathrm{R}_{\mathrm{t}}=\sum_{\mathrm{s}=0}^{\infty}(1+\mathrm{r})^{-\mathrm{s}+1}\left(\Delta \mathrm{R}_{\mathrm{t}+\mathrm{s}}-\Delta \mathrm{G}_{\mathrm{t}+\mathrm{s}}+\mathrm{rD}_{\mathrm{t}+\mathrm{s}-1}\right)+\lim _{\mathrm{s} \rightarrow \infty}(1+\mathrm{r})^{-\mathrm{s}-1} \mathrm{D}_{\mathrm{t}+\mathrm{s}}
$$

where $G$ represents government expenditure including the interest payment on public debt.

Let $R_{t}$ and $G_{t}$ be non-stationary such that $R_{t}=c_{R}+R_{t-1}+\mu_{1 t}$ and $G_{t}=c_{G}+G_{t-1}+\mu_{2 t}$. Then following Baharumshah and Lau (2007), Eq. (4) is written as:

$$
\mathrm{G}_{\mathrm{t}}=\mathrm{c}+\mathrm{R}_{\mathrm{t}}+\lim _{\mathrm{s} \rightarrow \infty}(1+\mathrm{r})^{-\mathrm{s}-1} \mathrm{D}_{\mathrm{t}+\mathrm{s}}+\mu_{\mathrm{t}}
$$

where $\mathrm{c}=(1+\mathrm{r}) \mathrm{r}^{-1}\left(\mathrm{c}_{\mathrm{R}}-\mathrm{c}_{\mathrm{G}}\right)$ and $\mu_{\mathrm{t}}=\sum_{\mathrm{s}=0}^{\infty}\left(\mu_{1 \mathrm{t}}-\mu_{2 \mathrm{t}}\right)(1+\mathrm{r})^{1-\mathrm{s}}$. Eq. (5) provides the basis for testing the sustainability of the fiscal imbalance. Assuming no Ponzi financing for which the limit term goes to zero, the cointegration relationship of government revenue and expenditure may be determined by:

$$
\mathrm{R}_{\mathrm{t}}=\mathrm{c}_{0}+\beta_{1} \mathrm{G}_{\mathrm{t}}+\varepsilon_{1 \mathrm{t}}
$$

where $\varepsilon_{1 \mathrm{t}}$ is the model distrurbance term. According to Martin (2000), the fiscal deficit is 'strongly' sustainable (strong solvency) when $\mathrm{R}$ and $\mathrm{G}$, as I(1) variables, are cointegrated with the vector [1,-1] (or in other words, when $\beta_{1}=1$ ). The fiscal imbalance is ‘weakly' sustainable when $\mathrm{R}$ and $\mathrm{G}$ hold a cointegration relationship with $0<\beta_{1}<1$ (Quintos, 1995). The fiscal deficit is not sustainable when $\beta_{1}=0$. The case of $\beta_{1}>1$ implies that expenditure grows more slowly than revenue which is inconsistent with a deficit.

\subsubsection{Model 2 - Sustainability of public debt}

Model 2 is a model-based test of public debt sustainability that incorporates a fiscal policy rule with Bohn's (1998) FRF specification. The model is based on an expanded version of Eq. (3):

$$
\mathrm{ps}_{\mathrm{t}}=\mathrm{c}_{1}+\rho \mathrm{d}_{\mathrm{t}}+\sigma_{1} \text { Yvar }_{\mathrm{t}}+\sigma_{2} \mathrm{Gvar}_{\mathrm{t}}+\varepsilon_{2 \mathrm{t}}
$$

\footnotetext{
${ }^{5}$ For detailed discussion, see Ferrarini and Ramayandi (2015); Mahmood et al. (2014); Dayaratna-banda and Priyadarshanee (2014); Ekanayake (2011).
} 
where $\mathrm{d}_{\mathrm{t}}$ is lagged debt-to-GDP; Yvar $\mathrm{t}_{\mathrm{t}}$ is cyclical output; Gvar $_{\mathrm{t}}$ is cyclical government expenditure; and $\varepsilon_{2 \mathrm{t}}$ is the model disturbance term. Following Barro (1986), the variables Yvar and Gvar are constructed as follows: Yvar $_{t}=\left[\left(1-\frac{y_{t}}{y_{t}^{*}}\right)\left(\frac{g_{t}^{t}}{y_{t}}\right)\right]$, where $\mathrm{y}_{\mathrm{t}}$ is real GDP and $\mathrm{y}_{\mathrm{t}}^{*}$ is its trend value; and $\mathrm{Gvar}_{\mathrm{t}}=\frac{\left(\mathrm{g}_{\mathrm{t}}-\mathrm{g}_{\mathrm{t}}^{*}\right)}{\mathrm{y}_{\mathrm{t}}}$, where $\mathrm{g}_{\mathrm{t}}$ is government expenditure and $\mathrm{g}_{\mathrm{t}}^{*}$ is its trend value. Trend values are approximated with the Hodrick Prescott (HP) filter.

Fiscal policy follows a debt stabilizing rule if $\rho$ is greater than the real interest rate (Bohn, 1998; Daniel \& Shiamptanis, 2013; Mendoza \& Ostry, 2008). The coefficient $\sigma_{1}$ captures the sensitivity of the primary balance to cyclical output given the effects of automatic stabilizers and discretionary fiscal policy measures. A positive $\sigma_{1}$ denotes counter-cyclicality in fiscal policy (Barro, 1986). The coefficient $\sigma_{2}$ captures the sensitivity of the primary balance to cyclical expenditure and is hypothesized to show a negative impact with respect to increases in expenditure over the trend.

\subsection{Data description}

Data are for the period 1961-2018, at annual frequency due to lack of quarterly data for the fiscal variables of interest. The source of data for nominal government revenue, nominal government expenditure, primary balance-to-GDP ratio, debt-toGDP ratio, nominal primary expenditure, and nominal GDP is the Central Bank of Sri Lanka. The data series in nominal terms are deflated using a GDP deflator obtained from the International Monetary Fund. The time series plots of all the variables of the study are presented in Fig. 1. Total government revenue consists of tax revenue and non-tax revenue, whereas total government expenditure contains recurrent and capital expenditure.

As evident from Panel A of Fig. 1, Sri Lanka has experienced a persistent widening in the fiscal deficit since 1961 amid a steady rise in expenditure relative to revenue. The deficit averaged 7.8\% of GDP over this period. Sri Lanka's launch of

Panel A: Real government revenue and expenditure

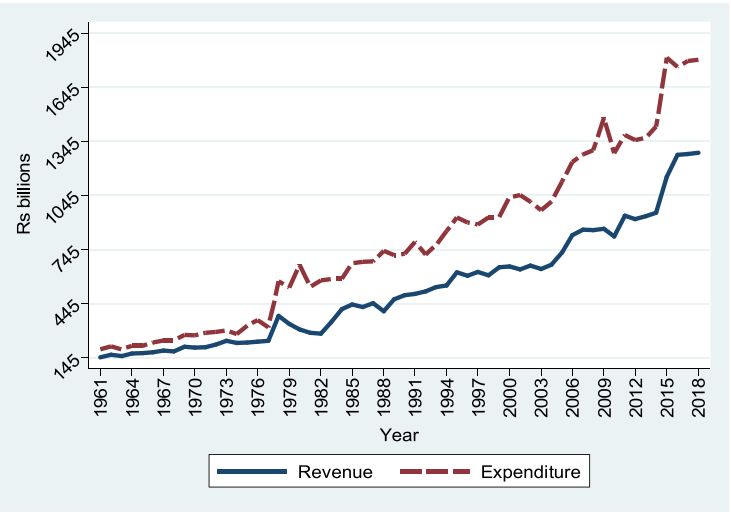

Panel C: Real GDP and cyclical output growth rate

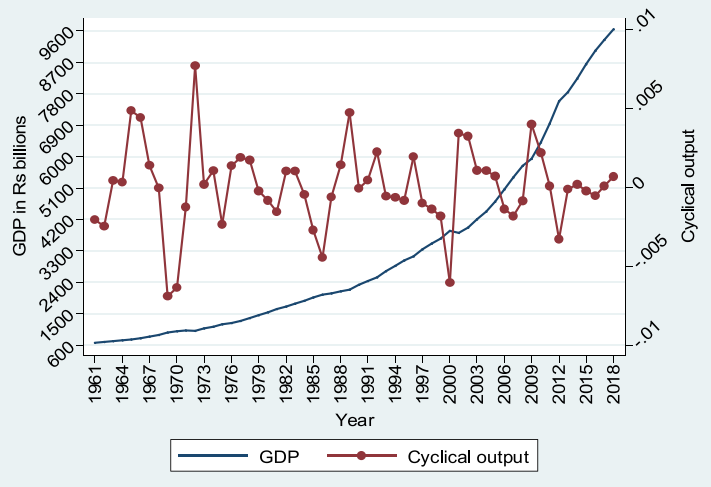

Panel B: Ratios to GDP of primary balance and debt

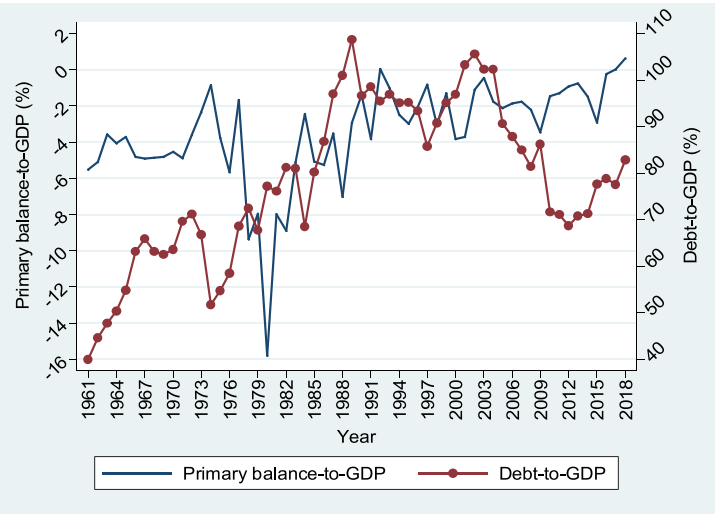

Panel D: Government expenditure net of interest on debt and cyclical expenditure growth rate

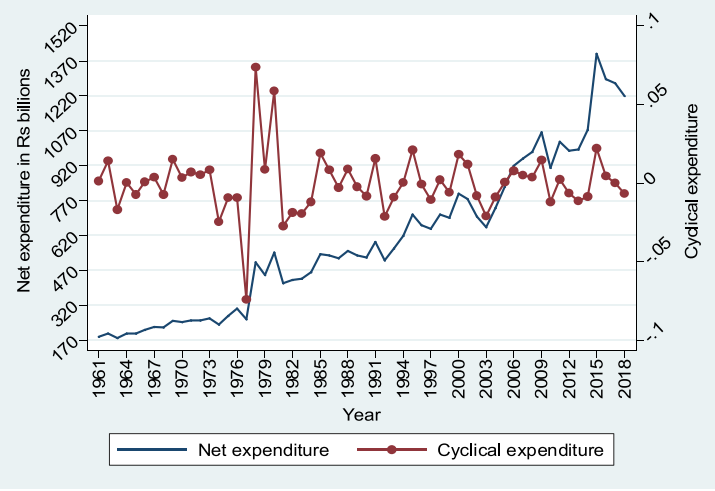

Fig. 1. Time series plots of model variables.

Panel A: Real government revenue and expenditure.

Panel B: Ratios to GDP of primary balance and debt.

Panel C: Real GDP and growth rate of cyclical output.

Panel D: Government expenditure net of interest on debt and cyclical expenditure growth rate. 
liberalization policies in 1977 is seen to have widened gap between expenditure and revenue while, as evident from Panel B, causing a sharp worsening in the primary deficit-to-GDP ratio. Khatri et al. (2017) showed that Sri Lanka has a low and declining revenue buoyancy given low tax productivity. They further showed that despite robust GDP growth, the declining revenue-to-GDP ratio and resulting financial constraints have led to a low expenditure-to-GDP ratio by international standards. Government expenditure grew sharply after 1977 primarily due to infrastructure investment. Further, the escalation of armed conflict between the government and separatist groups, which lasted almost 3 decades (1983-2009), elevated military spending and worsened the fiscal deficit to bring about double digit inflation.

Sri Lanka has piled up a great deal of public debt that has averaged 78.4\% of GDP over the 1961-2018 period. The debt-toGDP ratio peaked at $108.7 \%$ in 1989, and hovered over $100 \%$ from 2001 to 2004 before coming back down to $82.9 \%$ in 2018 . Persistent fiscal imbalances and high public debt levels have brought reliance on external borrowing that has exposed the economy to external shocks. Since Sri Lanka's graduation to lower middle-income status in 2010, the debt profile has shifted from concessional to nonconcessional foreign borrowing. As of 2019, the country has moved to upper middle-income status. In very recent years, factors such as low economic growth, currency depreciation, and high real interest rates have adversely contributed to the debt-to-GDP ratio (Central Bank of Sri Lanka, 2018).

Sri Lanka had an average annual growth rate of 4.7\% during the 1961-2018 period. Around this reference point, Panel C shows sharp fluctuations. Surges in growth were associated with the establishment of the independent Socialist Republic of Sri Lanka (1972), the Indo-Sri Lankan Peace Accord (1987), the cease fire agreement with the separatists (2002), and finally the end of internal conflict (2009). On the other hand, output contractions followed from the youth-led insurrection (1971), the eruption of armed conflict (1983), and a severe drought coupled with a terrorist attack on the main international airport (2001). The end of conflict in 2009 has brought a substantial peace dividend. However, Athukorala and Jayasuriya (2015) showed that despite the peace dividend, Sri Lanka has not achieved sustainable growth due to excessive reliance on debt that created a bubble which inevitably had to burst.

\subsection{Empirical methodology}

The first step in the empirical analysis of this study is to conduct unit root tests to check for stationarity of the time series variables. Testing for stationarity of the variables is a key step in specifying a time series model as the standard assumptions for asymptotic properties of estimators become invalid when a regression model contains non-stationary observations. The stationarity test results are given in Appendix A. The variables are found to be integrated at different orders, which has a bearing on model formulation.

The second step is to test for cointegration among the variables with structural breaks. Jha and Sharma (2004) show that inferences are robust when structural breaks are accommodated in the IBC model in testing for cointegration among fiscal variables. The Gregory and Hansen cointegration (GH test) holds prominence in testing for cointegration among variables while accommodating endogenously determined structural breaks (Gregory \& Hansen, 1996). The GH test offers four different models that impose different assumptions on the cointegrating vector. ${ }^{6}$ Using the GH test, this study explores the possibilities for accommodating structural breaks into the models.

The third step is to test for causality from government expenditure to government revenue. The direction of interdependence of government revenue and expenditure has significant implication for fiscal imbalances (Narayan, 2005). Toda and Yamamoto (1995) version of the Granger causality test is a simple approach, which requires the estimation of an augmented vector autoregressive model (VAR) to establish the potential predictive power of one variable for another based on modified Wald statistics. The Toda and Yamamoto causality test allows for causal inference in VARs at levels irrespective of their order of integration. This test avoids the concerns of ordinary tests for Granger causality that arise as a result of overlooking the non-stationary nature or cointegration of data series. The test of causality from government expenditure to government revenue is based on the following bivariate VAR $\left(k+d_{\max }\right)$ model, where $\mathrm{k}$ is the optimal lag length and $\mathrm{d}_{\text {max }}$ is the maximum order of integration:

$$
\begin{aligned}
& \mathrm{R}_{\mathrm{t}}=\alpha_{0}+\sum_{\mathrm{i}=1}^{\mathrm{k}} \alpha_{1 \mathrm{i}} \mathrm{R}_{\mathrm{t}-\mathrm{i}}+\sum_{\mathrm{j}=\mathrm{k}+1}^{\mathrm{d}_{\max }} \alpha_{2 \mathrm{j}} \mathrm{R}_{\mathrm{t}-\mathrm{j}}+\sum_{\mathrm{i}=1}^{\mathrm{k}} \beta_{1 \mathrm{i}} \mathrm{G}_{\mathrm{t}-\mathrm{i}}+\sum_{\mathrm{j}=\mathrm{k}+1}^{\mathrm{d}_{\max }} \beta_{2 \mathrm{j}} \mathrm{G}_{\mathrm{t}-\mathrm{j}}+\lambda_{1 \mathrm{t}} \\
& \mathrm{G}_{\mathrm{t}}=\omega_{0}+\sum_{\mathrm{i}=1}^{\mathrm{k}} \omega_{1 \mathrm{i}} \mathrm{G}_{\mathrm{t}-\mathrm{i}}+\sum_{\mathrm{j}=\mathrm{k}+1}^{\mathrm{d}_{\max }} \omega_{2 \mathrm{j}} \mathrm{G}_{\mathrm{t}-\mathrm{j}}+\sum_{\mathrm{i}=1}^{\mathrm{k}} \varphi_{1 \mathrm{i}} \mathrm{R}_{\mathrm{t}-\mathrm{i}}+\sum_{\mathrm{j}=\mathrm{k}+1}^{\mathrm{d}_{\max }} \varphi_{2 \mathrm{j}} \mathrm{R}_{\mathrm{t}-\mathrm{j}}+\lambda_{2 \mathrm{t}}
\end{aligned}
$$

where in Eq. (8), $G_{t}$ Granger causes $R_{t}$, if $\beta_{1 i} \neq 0 \forall_{i}$, and in Eq. (9), $R_{t}$ Granger causes $G_{t}$, if $\varphi_{1 i} \neq 0 \forall_{i}$. Four causal relationships may be identified between government revenue and expenditure: tax and spend; spend and tax; fiscal synchronization; and neutrality (Baharumshah \& Lau, 2007; Narayan, 2005).

\footnotetext{
${ }^{6}$ Different forms for the structural breaks are given as: level shift (GH_C); level shift with trend (GH_C/T); regime shift (GH_C/S); and regime with trend (GH_S/T). For detailed discussion, see Gregory \& Hansen, 1996, pp. 102-103.
} 
Step 4 is to apply the ARDL technique for parameter estimation, as the variables are integrated at different orders (see Appendix A). Regardless of the order of integration, the ARDL approach ascertains the long-run relationship among variables in a linear dynamic single equation system. The ARDL approach is widely used as a robust estimation technique even with a small sample size (Pesaran \& Shin, 1999). ARDL models of high lag orders overcome the problem of endogeneity and simultaneously correct for the serial correlation of residuals (Pesaran \& Shin, 1999; Pesaran, 2015). The generalized ARDL ( $\mathrm{p}_{\mathrm{i}}$, $\mathrm{q}_{\mathrm{i}}$ ) form for $\mathrm{R}_{\mathrm{t}}$ from Eq. (6) is given below with an unrestricted intercept, whereas ps from Eq. (7) is given with an unrestricted intercept and a restricted time trend: ${ }^{7}$

$$
\begin{aligned}
& \mathrm{R}_{\mathrm{t}}=\mathrm{c}_{0}+\sum_{\mathrm{j}=1}^{\mathrm{p}_{1}} \alpha_{\mathrm{j}} \mathrm{R}_{\mathrm{t}-\mathrm{j}}+\sum_{\mathrm{j}=0}^{\mathrm{q}_{1}} \beta_{\mathrm{j}} \mathrm{G}_{\mathrm{t}-\mathrm{j}}+\varepsilon_{3 \mathrm{t}} \\
& \mathrm{ps}_{\mathrm{t}}=\mathrm{c}_{1}+\mathrm{c}_{2} \text { trend }+\sum_{\mathrm{j}=1}^{\mathrm{p}_{2}} \tau_{\mathrm{j}} \mathrm{ps}_{\mathrm{t}-\mathrm{j}}+\sum_{\mathrm{j}=0}^{\mathrm{q}_{2}} \rho_{\mathrm{j}} \mathrm{d}_{\mathrm{t}-\mathrm{j}}+\sum_{\mathrm{j}=0}^{\mathrm{q}_{3}} \sigma_{1 \mathrm{j}} \text { Yvar }_{\mathrm{t}-\mathrm{j}}+\sum_{\mathrm{j}=0}^{\mathrm{q}_{4}} \sigma_{2 \mathrm{j}} \operatorname{Gvar}_{\mathrm{t}-\mathrm{j}}+\varepsilon_{4 \mathrm{t}}
\end{aligned}
$$

The coefficients of lagged dependent variables of $\alpha_{\mathrm{j}}$ and $\tau_{\mathrm{j}}$ are scalars, and $\beta_{\mathrm{j}}, \rho_{\mathrm{j}}, \sigma_{1 \mathrm{j}}$, and $\sigma_{2 \mathrm{j}}$ are row vectors of regressors, where $\mathrm{j}=0,1, \ldots, \mathrm{k}$, and $\varepsilon$ is the random disturbance term. The optimal lag structure of dependent variables $\left(p_{i}\right)$ and independent variables $\left(q_{i}\right)$, which possibly varies across the regressors, is chosen based on the Akaike Information Criterion (AIC). ${ }^{8}$ In ARDL, the dependent variable is a function of its lagged values as well as the contemporaneous and lagged values of the regressors.

Eq. (10) is reparameterized with the conditional error correction (EC) form to represent the speed of convergence to longrun equilibrium with the following specification:

$$
\Delta \mathrm{R}_{\mathrm{t}}=\mathrm{c}_{0}+\gamma_{1} \mathrm{R}_{\mathrm{t}-1}+\theta_{1} \mathrm{G}_{\mathrm{t}-1}+\sum_{\mathrm{j}=1}^{\mathrm{p}_{1}-1} \varphi_{1 \mathrm{j}} \Delta \mathrm{R}_{\mathrm{t}-\mathrm{j}}+\sum_{\mathrm{j}=0}^{\mathrm{q}_{1}-1} \varphi_{2 \mathrm{j}} \Delta \mathrm{G}_{\mathrm{t}-\mathrm{j}}+\varphi_{3} \text { dummy }_{\mathrm{t}}+\varepsilon_{3 \mathrm{t}}
$$

where the speed of adjustment parameter is $\gamma_{1}=-\left(1-\sum_{\mathrm{j}=1}^{\mathrm{p}_{1}} \alpha_{\mathrm{j}}\right)$; and the long-run coefficient of expenditure is $\beta_{1}=\frac{-\theta_{1}}{\gamma_{1}}$, where $\theta_{1}=\sum_{\mathrm{j}=0}^{\mathrm{q}_{1}} \beta_{\mathrm{j}}$. Similarly, Eq. (11) is reparameterized as:

$$
\begin{aligned}
\Delta \mathrm{ps}_{\mathrm{t}} & =\mathrm{c}_{1}+\mathrm{c}_{2} \text { trend }+\gamma_{2} \mathrm{ps}_{\mathrm{t}-1}+\theta_{2} \mathrm{~d}_{\mathrm{t}-1}+\theta_{3} \text { Yvar }_{\mathrm{t}-1}+\theta_{4} \text { Gvar }_{\mathrm{t}-1}+\sum_{\mathrm{j}=1}^{\mathrm{p}_{2}-1} \varphi_{4 \mathrm{j}} \Delta \mathrm{ps}_{\mathrm{t}-\mathrm{j}}+\sum_{\mathrm{j}=1}^{\mathrm{q}_{2}-1} \varphi_{5 \mathrm{j}} \Delta \mathrm{d}_{\mathrm{t}-\mathrm{j}} \\
& +\sum_{\mathrm{j}=1}^{\mathrm{q}_{3}-1} \varphi_{6 \mathrm{j}} \Delta \text { Yvar }_{\mathrm{t}-\mathrm{j}}+\sum_{\mathrm{j}=0}^{\mathrm{q}_{4}-1} \varphi_{7 \mathrm{j}} \Delta \mathrm{Gvar}_{\mathrm{t}-\mathrm{j}}+\varphi_{8} \text { dummy }_{\mathrm{t}}+\varepsilon_{4 \mathrm{t}}
\end{aligned}
$$

where the speed of adjustment parameter is $\gamma_{2}=-\left(1-\sum_{\mathrm{j}=1}^{\mathrm{p}_{2}} \tau_{\mathrm{j}}\right)$; and the long-run coefficients are derived as $\rho=\frac{-\theta_{2}}{\gamma_{2}}$, where $\theta_{2}=\sum_{\mathrm{j}=0}^{\mathrm{q}_{2}} \rho_{\mathrm{j}} \quad$ for the debt-to-GDP ratio; $\sigma_{1}=\frac{-\theta_{3}}{\gamma_{2}}$, where $\theta_{3}=\sum_{\mathrm{j}=0}^{\mathrm{q}_{3}} \sigma_{1 \mathrm{j}}$ for cyclical output; and $\sigma_{2}=\frac{-\theta_{4}}{\gamma_{2}}$, where $\theta_{4}=\sum_{\mathrm{j}=0}^{\mathrm{q}_{4}} \sigma_{2 \mathrm{j}}$ for expenditure cycles.

When Eq. (12) is estimated by ordinary least squares, the F-statistic $\left(F_{p s s}\right)$ is used to test the joint null hypothesis of no cointegration, $\mathrm{H}_{0}^{\mathrm{F}}:\left(\gamma_{1}=0\right) \cap\left(\sum_{\mathrm{j}=0}^{\mathrm{q}_{1}} \beta_{\mathrm{j}}=0\right)$, against the alternative hypothesis of $\mathrm{H}_{1}^{\mathrm{F}}:\left(\gamma_{1} \neq 0\right) \cup\left(\sum_{\mathrm{j}=0}^{\mathrm{q}_{1}} \beta_{\mathrm{j}} \neq 0\right)$. The statistic is compared against lower and upper bounds of the asymptotic critical values of Pesaran, Shin, and Smith (2001). If $\mathrm{H}_{0}^{\mathrm{F}}$ is rejected, the t-statistic for the single null hypothesis of $\mathrm{H}_{0}^{\mathrm{t}}: \gamma_{1}=0$ (versus $\mathrm{H}_{1}^{\mathrm{t}}: \gamma_{1} \neq 0$ ) is compared with its critical values. The rejection of $\mathrm{H}_{0}^{\mathrm{F}}$ or $\mathrm{H}_{0}^{\mathrm{t}}$ establishes the linear long-run cointegrating association of the underlying variables. The same procedure is applied for Eq. (13) to determine the linear long-run relationship among the variables.

Then the study moves one step further. Following Shin et al. (2014), a nonlinear feature is introduced into Bohn's FRF to capture the asymmetry in fiscal policy implementation via positive and negative partial sum decomposition of lagged debtto-GDP and cyclical output. Formally:

$$
\mathrm{ps}_{\mathrm{t}}=\rho^{+} \mathrm{d}_{t}^{+}+\rho^{-} \mathrm{d}_{t}^{-}+\sigma_{1}^{+} \mathrm{Yvar}_{t}^{+}+\sigma_{1}^{-} \mathrm{Yvar}_{t}^{-}+\sigma_{2} \mathrm{Gvar}_{\mathrm{t}}+\varepsilon_{5 \mathrm{t}}
$$

\footnotetext{
7 See Pesaran et al. (2001, p. 295) for five cases of interest delineated for deterministic component specifications of the ARDL model.

${ }^{8}$ Among alternative lag selection criteria, such as the Schwarz Bayesian Criterion (BIC) and the Hannan Quinn Criterion (HQC), the AIC is chosen as the more efficient and best fit for the models, despite the critiques of non-consistency.
} 
where the NARDL $\left(\mathrm{p}_{\mathrm{i}}, \mathrm{q}_{\mathrm{i}}\right)$ specification of Bohn's FRF is as follows:

$$
\mathrm{ps}_{\mathrm{t}}=\sum_{\mathrm{j}=1}^{\mathrm{p}_{3}} \phi_{\mathrm{j}} \mathrm{ps}_{\mathrm{t}-\mathrm{j}}+\sum_{\mathrm{j}=0}^{\mathrm{q}_{5}}\left(\delta_{1 \mathrm{j}}^{+} \mathrm{d}_{\mathrm{t}-\mathrm{j}}^{+}+\delta_{1 \mathrm{j}}^{-} \mathrm{d}_{\mathrm{t}-\mathrm{j}}^{-}\right)+\sum_{\mathrm{j}=0}^{\mathrm{q}_{6}}\left(\delta_{2 \mathrm{j}}^{+} \mathrm{Yvar}_{\mathrm{t}-\mathrm{j}}^{+}+\delta_{2 \mathrm{j}}^{-} \mathrm{Yvar}_{\mathrm{t}-\mathrm{j}}^{-}\right)+\sum_{\mathrm{j}=0}^{\mathrm{q}_{7}} \delta_{3 \mathrm{j}} \mathrm{Gvar}_{\mathrm{t}-\mathrm{j}}+\varepsilon_{5 \mathrm{t}}
$$

The partial sums of positive and negative changes of regressors are determined on:

$$
\begin{aligned}
& \mathrm{d}_{\mathrm{t}}^{+}=\sum_{\mathrm{j}=1}^{\mathrm{t}} \Delta \mathrm{d}_{\mathrm{j}}^{+}=\sum_{\mathrm{j}=1}^{\mathrm{t}} \max \left(\Delta \mathrm{d}_{\mathrm{j}}, 0\right), \quad \mathrm{d}_{\mathrm{t}}^{-}=\sum_{\mathrm{j}=1}^{\mathrm{t}} \Delta \mathrm{d}_{\mathrm{j}}^{-}=\sum_{\mathrm{j}=1}^{\mathrm{t}} \min \left(\Delta \mathrm{d}_{\mathrm{j}}, 0\right), \\
& \operatorname{Yvar}_{\mathrm{t}}^{+}=\sum_{\mathrm{j}=1}^{\mathrm{t}} \Delta \operatorname{Yavr}_{\mathrm{j}}^{+}=\sum_{\mathrm{j}=1}^{\mathrm{t}} \max \left(\Delta \operatorname{Yvar}_{\mathrm{j}}, 0\right) \text { and } \operatorname{Yavr}_{\mathrm{t}}^{-}=\sum_{\mathrm{j}=1}^{\mathrm{t}} \Delta \operatorname{Yvar}_{\mathrm{j}}^{-}=\sum_{\mathrm{j}=1}^{\mathrm{t}} \min \left(\Delta \operatorname{Yavr}_{\mathrm{j}}, 0\right) .
\end{aligned}
$$

Eq.(15) is reparameterized in conditional EC form to incorporate the speed of convergence to long-run equilibrium as follows:

$$
\begin{aligned}
\Delta \mathrm{ps}_{\mathrm{t}} & =\mathrm{c}_{3}+\gamma_{3} \mathrm{ps}_{\mathrm{t}-1}+\theta_{5}^{+} \mathrm{d}_{\mathrm{t}-1}{ }^{+}+\theta_{5}^{-} \mathrm{d}_{\mathrm{t}-1}{ }^{-}+\theta_{6}^{+} \mathrm{Yvar}_{\mathrm{t}-1}{ }^{+}+\theta_{6}^{-} \mathrm{Yvar}_{\mathrm{t}-1}{ }^{-}+\theta_{7} \operatorname{Gvar}_{\mathrm{t}-1}+\sum_{\mathrm{j}=1}^{\mathrm{p}_{3}-1} \omega_{\mathrm{j}} \Delta \mathrm{ps}_{\mathrm{t}-\mathrm{j}} \\
& +\sum_{\mathrm{j}=0}^{\mathrm{q}_{5}-1}\left(\emptyset_{1 \mathrm{j}}^{+} \Delta \mathrm{d}_{\mathrm{t}-\mathrm{j}}^{+}+\emptyset_{1 \mathrm{j}}^{-} \Delta \mathrm{d}_{\mathrm{t}-\mathrm{j}}{ }^{-}\right)+\sum_{\mathrm{j}=0}^{\mathrm{q}_{6}-1}\left(\emptyset_{2 \mathrm{j}}^{+} \Delta \operatorname{Yvar}_{\mathrm{t}-\mathrm{j}}{ }^{+}+\emptyset_{2 \mathrm{j}}^{-} \Delta \operatorname{Yvar}_{\mathrm{t}-\mathrm{j}}{ }^{-}\right)+\sum_{\mathrm{j}=0}^{\mathrm{q}_{7-1}} \emptyset_{3 \mathrm{j}} \operatorname{Gvar}_{\mathrm{t}-\mathrm{j}}+\varepsilon_{5 \mathrm{t}}
\end{aligned}
$$

where the speed of adjustment parameter is $\gamma_{3}=-\left(1-\sum_{\mathrm{j}=1}^{\mathrm{p}_{3}} \phi_{\mathrm{j}}\right) ;$ and $\omega_{\mathrm{j}}=-\sum_{i=j+1}^{\mathrm{p}_{3}} \phi_{i}$ for $\mathrm{j}=1, \ldots, \mathrm{p}_{3}-1 ; \theta_{5}^{+}=\sum_{\mathrm{j}=0}^{\mathrm{q}_{5}} \delta_{1 \mathrm{j}}^{+}$; $\theta_{5}^{-}=\sum_{\mathrm{j}=0}^{\mathrm{q}_{5}} \delta_{1 \mathrm{j}}^{-} ; \theta_{6}^{+}=\sum_{\mathrm{j}=0}^{\mathrm{q}_{6}} \delta_{2 \mathrm{j}}^{+} ; \theta_{6}^{-}=\sum_{\mathrm{j}=0}^{\mathrm{q}_{6}} \delta_{2 \mathrm{j}}^{-} ;$and $\theta_{7}=\sum_{\mathrm{j}=0}^{\mathrm{q}_{7}} \delta_{3 \mathrm{j}}$. The asymmetric long-run parameters of increasing and decreasing lagged debt are derived as $\rho^{+}=\frac{-\theta_{5}^{+}}{\gamma_{3}}$ and $\rho^{-}=\frac{-\theta_{5}^{-}}{\gamma_{3}}$. As with the symmetric ARDL model, the asymmetric ARDL model deals with the joint concerns of non-stationarity and nonlinear cointegration of variables to allow for long-run and short-run statistical inferences. The NARDL technique disallows weak endogeneity of the regressors and serial correlation of the error term.

Once Eq. (16) is estimated, the bounds testing approach of Pesaran et al. (2001) is used to establish the presence of an asymmetric long-run relationship among the variables. Three types of asymmetry are provided for in an NARDL model, namely (i) long-run asymmetries linked to $\rho^{+} \neq \rho^{-}$and $\sigma_{1}^{+} \neq \sigma_{1}^{-}$; (ii) impact asymmetries between $\Delta \mathrm{d}_{\mathrm{t}}^{+}$and $\Delta \mathrm{d}_{\mathrm{t}}^{-}$and between $\Delta \mathrm{Yvar}_{\mathrm{t}}^{+}$and $\Delta \mathrm{Yvar}_{\mathrm{t}}^{-}$; and (iii) adjustment asymmetries determined based on model specification. The long-run cumulative-dynamic multiplier effects of lagged debt-to-GDP and cyclical output on $\mathrm{ps}_{\mathrm{t}}$ are evaluated as:

$$
\begin{aligned}
& \mathrm{m}_{\mathrm{h}}^{+}=\sum_{\mathrm{j}=0}^{\mathrm{h}} \frac{\partial \mathrm{ps}_{\mathrm{t}+\mathrm{j}}}{\partial \mathrm{d}_{\mathrm{t}}^{+}}, \mathrm{m}_{\mathrm{h}}^{-}=\sum_{\mathrm{j}=0}^{\mathrm{h}} \frac{\partial \mathrm{ps}_{\mathrm{t}+\mathrm{j}}}{\partial \mathrm{d}_{\mathrm{t}}^{-}}, \mathrm{h}=0,1,2 \ldots \\
& \mathrm{m}_{\mathrm{l}}^{+}=\sum_{\mathrm{j}=0}^{1} \frac{\partial \mathrm{ps}_{\mathrm{t}+\mathrm{j}}}{\partial \mathrm{Yvar}_{t}^{+}}, \mathrm{m}_{\mathrm{l}}^{-}=\sum_{\mathrm{j}=0}^{1} \frac{\partial \mathrm{ps}_{\mathrm{t}+\mathrm{j}}}{\partial \mathrm{Yvar}_{\mathrm{t}}^{-}}, \quad \mathrm{l}=0,1,2 \ldots
\end{aligned}
$$

By construction, when $\mathrm{h} \rightarrow \infty, \mathrm{m}_{\mathrm{h}}^{+} \rightarrow \rho^{+}$and $\mathrm{m}_{\mathrm{h}}^{-} \rightarrow \rho^{-}$. And when $\mathrm{l} \rightarrow \infty, \mathrm{m}_{1}^{+} \rightarrow \sigma_{1}^{+}$and $\mathrm{m}_{1}^{-} \rightarrow \sigma_{1}^{-}$.

Finally, many diagnostic tests are performed to ensure the stability of the models.

\section{Empirical results}

\subsection{Model 1 - Sustainability of fiscal imbalance}

Model 1 examines the sustainability of the fiscal imbalance using the intertemporal fiscal budget constraint. Given that both government revenue and expenditure are integrated of order I(1) (see Appendix A), the GH test is applicable to establish cointegration with structural breaks. The results are given in Table 1 . The cointegration test statistics of all four models reject the null hypothesis of no cointegration at the $10 \%$ significance level. The results suggest structural break dates of 1978 in the GH_C and GH_C/S models; 1977 in the GH_C/T model; and 1983 in the GH_S/T model.

These structural breaks coincide with major economic events in Sri Lanka. In 1977, Sri Lanka shifted its economic policies from heavy government control and import substitution to market orientation and trade openness, with the consequences manifest in 1978. The year 1983 saw the adverse impact of the 'Black-July' riots with growth slowing amidst weakening investor sentiment and government expenditure rising due to the escalation of armed conflict between the government and separatist groups. These structural breaks imply that the fiscal process may have experienced regime shifts, which must be accommodated in modelling the IBC to establish cointegration between the fiscal variables. In line with the GH test results, two binary step dummies for openness (1977) and instability (1983 to 2009 when internal conflict ended) are introduced in 
Table 1

GH cointegration test for regime shifts in government revenue and expenditure.

\begin{tabular}{|c|c|c|c|}
\hline Model & Test statistic & $5 \%$ Critical value & Break point \\
\hline \multicolumn{4}{|l|}{ GH_C } \\
\hline $\mathrm{ADF}$ & $-5.87^{* * *}$ & -4.61 & 1978 \\
\hline $\mathrm{Zt}$ & $-5.92^{* * *}$ & -4.61 & 1978 \\
\hline $\mathrm{Za}$ & $-45.32^{* *}$ & -40.48 & 1978 \\
\hline \multicolumn{4}{|l|}{ GH_C/T } \\
\hline $\mathrm{ADF}$ & $-5.41^{* *}$ & -4.99 & 1977 \\
\hline $\mathrm{Zt}$ & $-5.46^{* * *}$ & -4.99 & 1977 \\
\hline $\mathrm{Za}$ & -41.36 & -47.96 & 1977 \\
\hline \multicolumn{4}{|l|}{ GH_C/S } \\
\hline $\mathrm{ADF}$ & $-5.84^{* * *}$ & -4.95 & 1978 \\
\hline $\mathrm{Zt}$ & $-5.89^{* * *}$ & -4.95 & 1978 \\
\hline $\mathrm{Za}$ & $-44.99^{*}$ & -47.04 & 1978 \\
\hline \multicolumn{4}{|l|}{ GH_S/T } \\
\hline $\mathrm{ADF}$ & $-5.65^{* *}$ & -5.50 & 1983 \\
\hline $\mathrm{Zt}$ & $-5.75^{* *}$ & -5.50 & 1983 \\
\hline $\mathrm{Za}$ & -44.44 & -58.58 & 1983 \\
\hline
\end{tabular}

Notes:

***, **, and ${ }^{*}$ denote $H_{0}$ is rejected at $1 \%, 5 \%$, and $10 \%$ significance levels, respectively.

The structural breaks are selected when the absolute values of the test statistics are greater than the $5 \%$ critical values and the minimum of ADF, $\mathrm{Zt}$, and $\mathrm{Za}$.

Table 2

Results of Granger non-causality test.

\begin{tabular}{|c|c|c|c|}
\hline \multirow[t]{2}{*}{ Null hypothesis } & \multicolumn{2}{|c|}{ Test statistics } & \multirow[t]{2}{*}{ Decision } \\
\hline & Chi-sq & p-value & \\
\hline Government expenditure does not Granger cause government revenue & 28.75 & 0.000 & Reject null at $1 \%$ significance level \\
\hline Government revenue does not Granger cause government expenditure & 20.06 & 0.005 & Reject null at $1 \%$ significance level \\
\hline
\end{tabular}

Model 1. Further, 'expenditure trend' is introduced as an interaction term between instability and expenditure to capture the escalating nature of expenditure during the period of civil unrest. All the dummy variables are deterministic regressors in Model 1.

Results of the Toda and Yamamoto Granger non-causality test, which is aimed at identifying the causal nexus between revenue and expenditure, are presented in Table 2 . The study rejects null hypotheses of both 'expenditure does not cause revenue' and 'revenue does not cause expenditure' at the $1 \%$ significance level. These results suggest the existence of bidirectional causality from government expenditure to revenue and government revenue to expenditure. This finding of fiscal synchronization implies that the authorities make concurrent decisions on government spending and revenue such that these variables reinforce each other. According to Narayan (2005), the decisions on expenditure and revenue are based on marginal benefit to the government versus marginal cost to the citizens. Barro (1979) tax smoothing model, which is based on Ricardian equivalence, gives further credence to this hypothesis. The model holds that today's debt-financed government spending causes future tax increases. However, the evidence of bi-directional causality in this study is contrary to Narayan's (2005) finding for Sri Lanka during 1960-2000, which points to 'tax and spend' behavior in the short-run and 'spend and tax' behavior in the long-run.

Results for estimation of Eq. (12) using a symmetric ARDL approach are presented in Table 3. The long-run coefficient estimate of expenditure $\left(\beta_{1}\right)$ is 0.752 , significant at a $1 \%$ level. This means that for every one rupee increase in expenditure, revenue rises by only 0.75 rupees. In other words, government revenue grows at a slower rate than government expenditure. This condition indicates that Sri Lanka's fiscal imbalance is on a path of weak sustainability. As a result, the undiscounted value of public debt does not tend to zero in the long run and the transversality condition of the IBC does not hold. This finding implies that the public debt path is unsustainable for Sri Lanka.

In the short-run, the coefficient of openness is negative, and both statistically and economically significant. Due to its farreaching structural change in 1977, Sri Lanka's government revenue shifted down to a new level, in line with Peacock and Wiseman (1961) displacement effects. The drop in revenue was mostly attributable to a decrease in tariff revenue, which accounted for a major share of government revenue. Athukorala (2012) described reasons for tariff revenue to drop in the face of tariff rate increases after trade liberalization. ${ }^{9}$

The coefficient of instability is positive, and both statistically and economically significant. The positive value indicates that in the face of a ballooning war expenditure needs, the government managed to raise revenue to secure stability.

\footnotetext{
${ }^{9}$ Athukorala (2012) discussed three reasons for government revenue to decrease with import tariff increases. First, high import duties are prohibitive and destroy imports. Second, duty-free entry is made available under incentive schemes to promote local manufacturers. Third, importers evade high duties.
} 
Table 3

L Model 1 ARDL estimation results for long-run and short-run.

\begin{tabular}{|c|c|c|}
\hline Variable & Coefficient & Standard error \\
\hline \multicolumn{3}{|l|}{ Long-run estimations } \\
\hline Expenditure & $0.752^{* * *}$ & 0.027 \\
\hline \multicolumn{3}{|l|}{ Short-run estimations } \\
\hline$\Delta$ Revenue $_{\mathrm{t}}$ & $0.182^{*}$ & 0.102 \\
\hline Openness & $-61.450^{* * *}$ & 18.338 \\
\hline Instability & $90.755^{* * *}$ & 32.201 \\
\hline Expenditure trend & $-0.0001^{* * *}$ & 0.000 \\
\hline Constant & 1.662 & 9.215 \\
\hline Error correction term & $-0.626^{* * *}$ & 0.084 \\
\hline \multicolumn{3}{|l|}{ Diagnostic tests } \\
\hline $\mathrm{F}_{\mathrm{pss}}$ & & 33.677 \\
\hline R-squared & & 0.597 \\
\hline Adjusted R-squared & & 0.547 \\
\hline Durbin-Watson test for serial correlation & & 2.016 \\
\hline Breusch-Pagan test for heteroskedasticity & & $0.02[0.883]$ \\
\hline White's test for homoskedasticity & & $24.46[0.324]$ \\
\hline S-K normality test & & $2.20[0.333]$ \\
\hline CUSUM test of model stability & & Stable at the $5 \%$ significance level $^{a}$ \\
\hline
\end{tabular}

Athukorala (2012) emphasized that against the pressing need to increase import-tariff revenue to finance war costs from 1983, the trade liberalization policy had to be delayed.

A long-run relationship between government revenue and expenditure is supported by the F-statistic $\left(\mathrm{F}_{\mathrm{pss}}\right)$. The coefficient of the error correction term $\left(\gamma_{1}\right)$ shows a quick significant reversion of $62.6 \%$ a year to return to the long-run steady state after a disturbance. Post-estimation diagnostic tests show that the underlying assumptions of normality, homoscedasticity, and no autocorrelation are fulfilled and the coefficients are stable over time.

\subsection{Model 2 - Sustainability of public debt}

Model 2 is used to test for public debt sustainability using Bohn's FRF framework. Unit root tests indicate that the variables are integrated of order zero or one, with no variables integrated of order two (see Appendix A). Since the variables are integrated at different orders, application of the GH test is not viable. Based on prior information and consistent with Model 1, plausible structural dummies of openness and instability are introduced into Eq. (13) with the assumption that fiscal processes were interrupted by Sri Lanka's trade liberalization policies and internal conflict. In fact, in Fig. 1 the break point of 1977 is evident from plots of the primary balance and cyclical expenditure.

Table 4 shows the estimation results of Eq. (13) using the ARDL technique. The $\mathrm{F}_{\mathrm{pss}}$ statistic falls outside the critical value bounds of Pesaran et al. (2001) meaning the null hypothesis, that coefficients of lagged variables are jointly equal to zero, is rejected. The study finds statistically significant evidence in favor of a long-run relationship among primary balance, lagged debt-to-GDP ratio, cyclical output, and cyclical expenditure.

The coefficient of the lagged debt-to-GDP ratio $(\rho)$, the main variable of interest of this study, is positive, but neither economically nor statistically significant. This indicates a weak response of the primary balance to a build-up of public debt, thus undermining the sustainability of that debt. The implication is that the sufficient condition for sustainability of fiscal policy is not met. This is consistent with the observed reality that Sri Lanka's debt-to-GDP ratio has risen swiftly in connection with an ever widening gap between government revenue and spending. Other studies have come to similar conclusions using different methodologies. For instance, Chua et al. (2018) determined that Sri Lanka's fiscal policy violated the strict debt-stabilization condition in the sense that the rate of output growth exceeded the real interest rate. In the same vein, Mahmood, Farooq-Arby, and Sherazi (2014) found that Sri Lanka along with three major countries of the South Asian Association for Regional Cooperation experienced major debt burden episodes caused by significant imbalances in fiscal and current accounts.

The estimated negative coefficient of the cyclical output $\left(\sigma_{1}\right)$ provides evidence of procyclicality in the fiscal stance in Sri Lanka, meaning the primary balance deteriorates in economic upturns, and vice versa. The coefficient of cyclical expenditure $\left(\sigma_{2}\right)$ indicates a statistically and economically strong negative impact on the primary balance, as expected. In the short-run, economic opening has the effect of reducing the primary balance, as explained by the drop in tariff revenue that results from trade liberalization (Athukorala, 2012). The error correction term, which captures the pace of adjustment between the shortrun dynamics and the long-run equilibrium, shows a statistically significant coefficient of -0.539 . This implies that the system has corrected from disequilibrium at a speed of $53.9 \%$ a year to reach equilibrium. 
Table 4

Model 2 ARDL estimation results for long-run and short-run.

\begin{tabular}{lll}
\hline Variable & Coefficient & Standard error \\
\hline Long-run estimations & & 0.046 \\
Lagged debt & 0.054 & 2.764 \\
Yvar & -2.700 & 0.381 \\
Gvar & $-1.596^{* * *}$ & 0.000 \\
Trend & $0.002^{* * *}$ & 0.168 \\
Short-run estimations & & 0.088 \\
$\Delta$ Gavr $_{\mathrm{t}}$ & 0.108 & 1.055 \\
$\Delta \mathrm{Gavr}_{\mathrm{t}-1}$ & $0.227^{* *}$ & 0.866 \\
$\Delta$ Yavr $_{\mathrm{t}}$ & 0.701 & 0.732 \\
$\Delta$ Yavr $_{\mathrm{t}-1}$ & $1.756^{* *}$ & 0.009 \\
$\Delta$ Yavr $_{\mathrm{t}-2}$ & 1.104 & 0.007 \\
Openness & $-0.028^{* * *}$ & 0.521 \\
Instability & 0.005 & 0.118 \\
Constant & $-1.811^{* * *}$ & 6.090 \\
Error correction term & $-0.539^{* * *}$ & 0.833 \\
Diagnostic tests & & 0.785 \\
F $_{\text {pss }}$ & & 2.086 \\
R-squared & & $2.558[0.465]$ \\
Durbsted R-squared & & $55.0[0.437]$ \\
Breusch-Pagan test for heteroskedasticity & & $4.86[0.088]$ \\
White's test for homoskedasticity & & Stable at the 5\% significance level \\
S-K normality test & & \\
CUSUM test of model stability & & \\
\hline
\end{tabular}

Notes.

***, **, and ${ }^{*}$ denote $\mathrm{H}_{0}$ is rejected at $1 \%, 5 \%$, and $10 \%$ significance levels, respectively.

[] denotes probability values for diagnostic tests.

Table 4 reports a battery of post-estimation diagnostic statistics. The model contains spherical errors meaning the assumptions of homoscedasticity and no autocorrelation are fulfilled and the coefficients are stable over time. However, the error distribution seems skewed, perhaps due to extreme outliers which cannot be dropped from the model. Nau (2018) showed that the violation of normality may occur due to either: (i) the distribution of the dependent variable and/or regressors being considerably non-normal; and/or (ii) violation of the linearity assumption. Nau (2018) suggested that an asymmetric transformation of the variables may overcome these problems. Given the apparent misspecification involved with the symmetric ARDL model, an asymmetric formulation is required to obtain valid inferences.

Estimation of Eq. (16) using the NARDL technique provides an indication of asymmetry in fiscal policy and reveals important features of debt dynamics. The results are given in Table 5. The response coefficients vary across upturns and downturns in debt and cyclical output and between the short-run and the long-run. The estimated long-run coefficient of increasing debt $\left(\rho^{+}\right)$is statistically significant, and indicates that the primary balance has improved by $0.132 \%$ in response to a $1 \%$ rise in the lagged debt-to-GDP ratio. The estimated long-run coefficient of declining debt $\left(\rho^{-}\right)$is neither economically nor statistically significant indicating no clear correlation between the primary balance and a decline in the debt-to-GDP ratio. These findings provide strong evidence that the fiscal authorities undertook measures to reduce the long-run debt-to-GDP ratio when that ratio was on the rise. This approach may have been adopted to avert an upsurge in the debt-to-GDP ratio to an unprecedented level. The short-run negative statistically insignificant coefficient of declining debt $(-0.043)$ implies that the primary balance has deteriorated at the decline of public debt in the short-run. These findings imply that Sri Lanka has lacked a consistent fiscal consolidation program to ensure the sustainability of public debt in the short-run and the long-run.

Stabilization effects of fiscal policy vary over the business cycle with a much stronger and statistically significant impact in economic expansions than in contractions. The estimated coefficient of positive cyclical output $\left(\sigma_{1}^{+}=-5.956\right)$ indicates that the primary balance has fell in cyclical upswings. The coefficient of negative cyclical output $\left(\sigma_{1}^{-}=4.048\right)$ shows a statistically insignificant increase in the primary balance during cyclical downswings. As a result, in the long run the primary balance has deteriorated in economic booms, whereas it has improved in economic recessions. In the short-run, the primary balance has declined in both cyclical upswings $(-0.019)$ and cyclical downturns (1.334). Though these coefficients are statistically insignificant, in line with evidence from the literature, these results exhibit the expansionary stance of Sri Lanka's fiscal policy in the short run. Jha (2010) attributed such asymmetry in fiscal policy in developing countries to a narrow tax base and inelasticity in government expenditure due to political factors. Therefore, government revenue and expenditure both rise in economic booms while both contract in recessions. Alesina, Campante, and Tabellini, 2008, p.1033) claimed that 'procyclicality of fiscal policy is more often driven by a distorted policy reaction to booms, rather than to recessions'.

As with the symmetric model, the coefficient of cyclical expenditure shows that the primary balance has deteriorated substantially due to an increase in expenditure over its trend. As expected, the dummy for openness shows a statistically and economically significant negative effect attributable to a drop in tariff revenue. The statistically significant negative EC term 
Table 5

Model 2 NARDL estimation results for long-run and short-run.

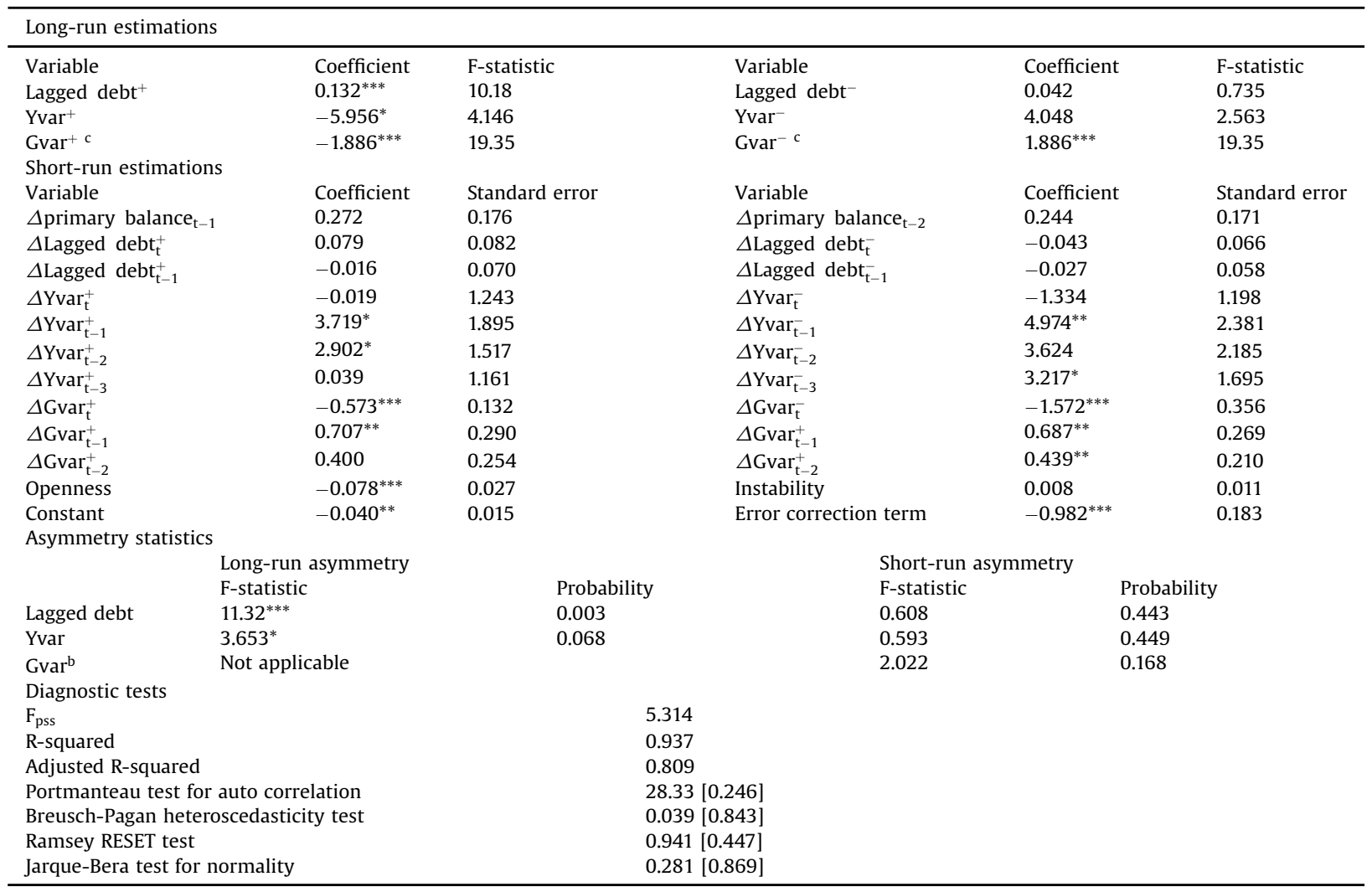

Notes.

${ }^{* * *},{ }^{* *}$, and ${ }^{*}$ denote $\mathrm{H}_{0}$ is rejected at $1 \%, 5 \%$, and $10 \%$ significance levels, respectively.

[] denotes probability values for diagnostic tests.

bThe long-run asymmetry of GVAR is constrained.

implies that the system corrects its previous year's disequilibrium swiftly providing further evidence of a stable long-run correlation among the variables of the model.

Estimation of Bohn's FRF for Sri Lanka yields robust evidence for asymmetries in fiscal policy, particularly in the long-run. According to Wald test statistics, the null hypothesis of a long-run summative symmetric relationship between the primary balance and debt is rejected at a $1 \%$ significance level, whereas the null hypothesis of a long-run summative symmetric relationship between the primary balance and cyclical output is rejected at a $10 \%$ significance level. However, the Wald test statistics do not provide evidence to reject the null hypothesis of a summative symmetric relationship in the short-run for either relationship. The estimated model satisfies the diagnostic tests for normality, homoscedasticity, no autocorrelation, and adequacy of the dynamic specifications at a $1 \%$ significance level. The explanatory power of the asymmetric FRF is quite high as represented by an R-squared of $93.7 \%$ and an adjusted R-squared of $80.9 \%$, although the adjusted R-squared may be biased given the small sample size of 58 data points. Of note, other studies that have tested for the sustainability condition of Bohn (1998) have exhibited high adjusted R-squared values (see, for instance, Aldama and Creel (2018) on the sustainability of US public debt which reports an adjusted R-squared of 93\%).

The dynamic responses of the primary balance to positive or negative shocks of regressors are plotted in Fig. 2 . The adjustment patterns are derived using the dynamics of the model to combine the coefficients of long-run parameters and the EC term. As per Panel A, the primary balance improves significantly following a positive shock to the debt-to-GDP ratio, and achieves its full adjustment to a new equilibrium within four to five years. In contrast, the primary balance shows only modest improvement in response to a negative shock to the debt-to-GDP ratio, and this dies out very quickly. Panel B reveals that the dynamic adjustment of the primary balance in response to a shock to cyclical output growth is more prolonged. In response to a cyclical upswing, the primary balance declines over four years and remains significantly lower in the new equilibrium. In response to a cyclical downturn, the primary balance is initially little effected but begins to rise at three years and is significantly strengthened in the long run. Finally, Panel $C$ shows a rapid adjustment in the primary balance to a shock to cyclical government expenditure, with, as expected, an increase in expenditure decreasing the primary balance and a decrease in expenditure increasing the primary balance. 


\section{Panel A: Shock to debt-to-GDP ratio}

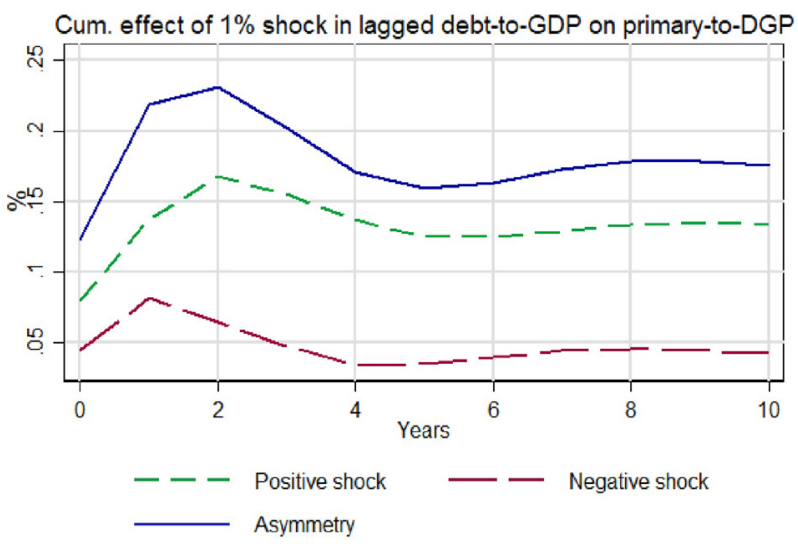

Panel B: Shock to cyclical output

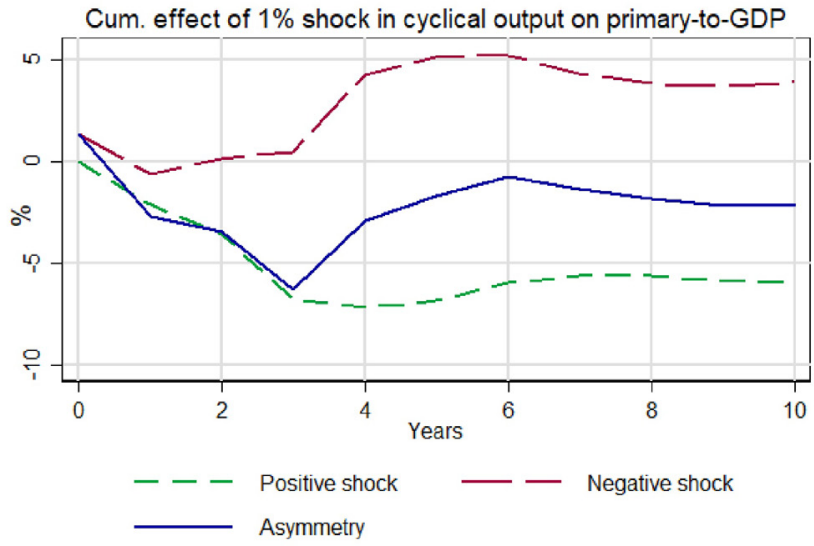

Panel C: Shock to cyclical government expenditure

Cum. effect of $1 \%$ shock in expenditure cycle on primary-to-GDP

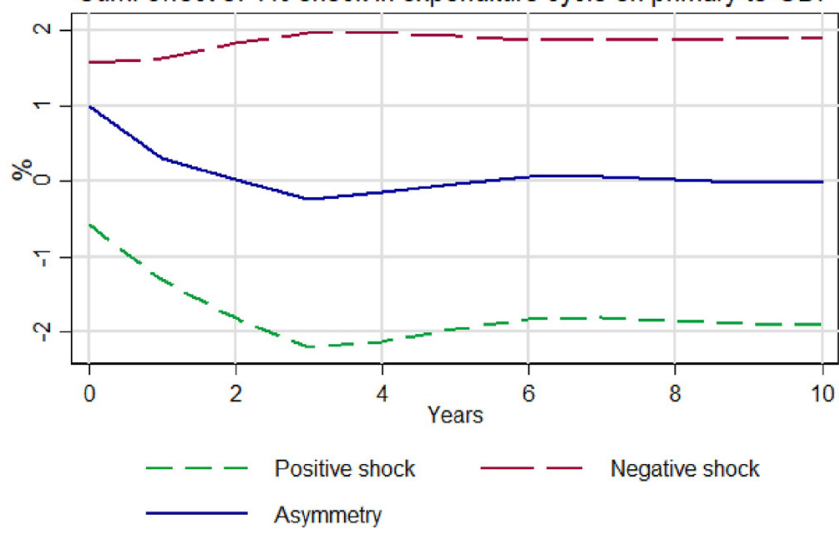

Fig. 2. Response of primary balance to positive and negative shocks to regressors.

Panel A: Shock to debt-to-GDP ratio.

Panel B: Shock to cyclical output.

Panel C: Shock to cyclical government expenditure. 


\section{Conclusion and policy recommendations}

The sustainability of fiscal policy has been a growing concern in Sri Lanka fueled by a rising budget deficit and ever more burdensome public debt. To assess the sustainability of the fiscal imbalance and public debt, the extant literature offers various approaches, the results of which are sensitive to the assumptions involved. This paper models, first, adjustment in government revenue to a government expenditure shock based on an intertemporal budget constraint and, second, adjustment in the primary fiscal balance to exogenous shocks based on Bohn's fiscal reaction function. The models are applied to annual data for Sri Lanka for the period 1961-2018 to test for sustainability of the fiscal imbalance and the public debt-to-GDP ratio. Since the variables are non-stationary, ARDL estimation techniques are applied.

The results for symmetric ARDL estimation of the intertemporal budget constraint indicate that Sri Lanka's fiscal imbalance is inconsistent with the strong form sustainability condition. More tellingly, a nonlinear approach to estimating Sri Lanka's fiscal policy responses to shocks reveals an asymmetry between positive and negative shocks. The asymmetry is accommodated in modelling via positive and negative partial sum decompositions of the regressors of the fiscal reaction function. Inclusion of the asymmetric features into the model overcomes the misspecification implicit in the symmetric model. Estimation results confirm that overlooking these nonlinearities in modelling could lead to misleading inferences.

Strong evidence emerges that fiscal authorities attempt to stabilize the debt-to-GDP ratio through fiscal consolidation when the ratio is on the rise. In particular, the authorities appear to moderate upsurges in the debt-to-GDP ratio to keep it from reaching unprecedented heights. This finding runs contrary to the consensus view that Sri Lanka's public debt is on an unsustainable path. Nevertheless, consistent with general observation, the study finds that Sri Lanka's fiscal consolidation efforts show a lack of dedication and a tendency to dawdle in the absence of serious pressure. Thus, a weak form of sustainability of public debt may be said to hold for Sri Lanka.

In view of the above findings, a few policy suggestions may be offered for Sri Lanka to move toward a more consistent and disciplined course in reducing its public debt. Sri Lanka needs to improve government cash flow via an expansion in the tax base. In this regard, the country has already made a concerted effort by passing the Inland Revenue Act, No. 24 of 2017 and implementing the Revenue Administration Management Information System (RAMIS) to simplify, standardize, and rationalize the tax system. On the spending side, Sri Lanka will need to marshall the political will to rein in the government and its agencies. Debt management should be integrated into the overall fiscal policy framework of the country. In the face of any cyclical retrenchment in the debt-to-GDP ratio, the fiscal authorities should pursue a sustained consolidation strategy to achieve lasting progress toward restoring debt sustainability.

\section{Acknowledgements}

I am sincerely thankful to Professor Raghbendra Jha, two anonymous referees of the Journal of Asian Economics, and seminar participants at Australian National University for their valuable comments and suggestions. This research is supported by an Australian Government Research Training Program (RTP) Scholarship.

\section{Appendix A.}

Table A1

Table A1

Unit-root test results.

\begin{tabular}{|c|c|c|c|c|c|c|}
\hline Variables & ADF test & & & & KPSS test & \\
\hline & Level & & First difference & & Level & First diffrence \\
\hline & Intercept & Intercept and trend & Intercept & Intercept and trend & Trend & Trend \\
\hline Government revenue & 1.622 & -1.058 & $-6.924^{* * *}$ & $-7.366^{* * *}$ & 0.799 & $0.427^{* * *}$ \\
\hline Government expenditure & 0.530 & -2.756 & $-10.122^{* * *}$ & $-10.418^{* * *}$ & 0.644 & $0.019^{* * * *}$ \\
\hline Primary balance-to-GDP & $-3.603^{*}$ & $-4.497^{*}$ & $-12.353^{* * *}$ & $12.254^{* * *}$ & 0.224 & $0.0155^{* * *}$ \\
\hline Headline deficit-to-GDP & $-3.904^{* *}$ & $-3.873^{* *}$ & $-12.452^{* * *}$ & $-12.393^{* * *}$ & 0.535 & $0.152^{* * * *}$ \\
\hline Debt-to-GDP & -2.379 & -1.920 & $-7.205^{* * *}$ & $-7.325^{* * *}$ & 1.03 & $0.045^{* * *}$ \\
\hline Yvar & $-5.511^{* * *}$ & $-5.462^{* * *}$ & Not applicable & Not applicable & $0.024^{* * *}$ & Not applicable \\
\hline Gvar & $-9.031^{* * *}$ & $-8.948^{* * *}$ & Not applicable & Not applicable & $0.014^{* * *}$ & Not applicable \\
\hline
\end{tabular}

Notes.

a. ***, **, and * denote $H_{0}$ is rejected at $1 \%, 5 \%$, and $10 \%$ significance levels, respectively.

b. The null hypothesis of the Augmented Dicky Fuller (ADF) test is that the series has a unit root, while the null hypothesis of Kwiatkowski-PhillipsSchmidt-Shin (KPSS) stationarity test is that the series is stationary.

c. ADF rejects a unit root of the primary balance-to-GDP, while KPSS does not reject a unit root of the primary balance-to-GDP. Given the clear evidence of nonstationarity of the debt-to-GDP ratio, Bohn (2005, p. 10) suggested that the headline deficit and the primary deficit cannot both be stationary. The results show no strong evidence for stationarity in the primary balance-to-GDP at level. 


\section{References}

Abiad, A., \& Baig, T. (2005). Underlying factors driving fiscal effort in emerging market economies. IMF working papers, no. 05/106. 1-30.

Afonso, A., \& Toffano, P. (2013). Fiscal regimes in the EU. European Central Bank. Working paper, no. 1529.

Aldama, P., \& Creel, J. (2017). Fiscal policy in the US: Ricardian after all? OFCE working paper, no. 23. .

Alesina, A., Campante, F. R., \& Tabellini, G. (2008). Why is fiscal policy often procyclical? Journal of the European Economic Association, 6(5), $1006-1036$.

Athukorala, P. (2012). Sri Lanka's trade policy: Reverting to dirigisme? Working papers in Trade and Development, No. 2012/14. .

Athukorala, P., \& Jayasuriya, S. (2015). Victory in war and defeat in Peace: Politics and economics of post-conflict Sri Lanka. Asian Economic Papers, $14(3), 22-54$.

Baharumshah, A. Z., \& Lau, E. (2007). Regime changes and the sustainability of fiscal imbalance in East Asian countries. Economic Modelling, 24(6), 878-894.

Barro, R. J. (1979). On the determination of the public debt. The Journal of Political Economy, 87(5), 940-971.

Barro, R. J. (1986). U.S. Deficit since world war I. The Scandinavian Journal of Economics, 88(1), 195-222.

Behuria, A. K. (2018). How Sri Lanka walked into a debt trap, and the way out. Strategic Analysis, 42(2), 168-178.

Bohn, H. (1995). The sustainability of budget deficits in a stochastic economy. Journal of Money, Credit, and Banking, 27(1), 257-271.

Bohn, H. (1998). The behavior of US public debt and deficits. The Quarterly Journal of Economics, 113(3), 949-963.

Bohn, H. (2005). The sustainability of fiscal policy in the United States. CESifo Working Paper, no. 1446. 1-45.

Bohn, H. (2007). Are stationarity and cointegration restrictions really necessary for the intertemporal budget constraint? Journal of Monetary Economics, 54 (7), 1837-1847.

Camarero, M., Carrion-i-Silvestre, J. L., \& Tamarit, C. (2015). The relationship between debt level and fiscal sustainability in organization for economic cooperation and development countries. Economic Inquiry, 53(1), 129-149.

Celasun, O., Debrun, X., \& Ostry, J. D. (2006). Primary surplus behavior and risks to fiscal sustainability in emerging market countries: A "fan-chart" approach. IMF Working Papers, 53(no. 3), 401-425.

Central Bank of Sri Lanka (2018). Annual report 2018. Colombo: Central Bank of Sri Lanka.

Checherita-Westphal, C., \& Ždarek, V. (2017). Fiscal reaction function and fiscal fatigue: Evidence for the Euro Area. European Central Bank. Working paper, no. 2036.

Chen, P. F. (2016). US fiscal sustainability and the causality relationship between government expenditures and revenues: A new approach based on quantile cointegration. Fiscal Studies, 37(2), 301-320.

Chua, C. L., Perera, N., \& Suardi, S. (2018). Fiscal regimes and fiscal sustainability in Sri Lanka. Paper Presented at the 11th International Research Conference of Central Bank of Sri Lanka, https://www.cbsl.gov.lk/sites/default/files/cbslweb_documents/research/6_Sandy_Suardi_Full_text.pdf.

Daniel, B. C., \& Shiamptanis, C. (2013). Pushing the limit? Fiscal policy in the european monetary union. Journal of Economic Dynamics E Control, 37(11), $2307-2321$.

Dayaratna-banda, O., \& Priyadarshanee, A. (2014). Sustainability of government debt in Sri Lanka. International Journal of Business and Social Research, 4(7), $100-108$.

Ekanayake, I. (2011). Assessing government debt sustainability in Sri Lanka. Paper Presented at the 4th International Research Conference of Central Bank of Sri Lanka, viewed 3 January 2019 http://www.cbsl.gov.lk/pics_n_docs/10_pub/_docs/IRC/2011/Govt._Debt_Full.pdf.

Ferrarini, B., \& Ramayandi, A. (2015). Public debt sustainability in developing Asia: An update. ADB Economics Working Paper Series, no 468. .

Ghosh, A. R., Kim, J. I., Mendoza, E. G., Ostry, J. D., \& Qureshi, M. S. (2013). Fiscal fatigue, fiscal space and debt sustainability in advanced economies. The Economic Journal, 12(566), F4-F30.

Gregory, A. W., \& Hansen, B. E. (1996). Residual-based tests for cointegration in models with regime shifts. Journal of Econometrics, 70(1), 99-126.

Hakkio, C. S., \& Rush, M. (1991). Is the budget deficit too large? Economic Inquiry, 29(3), 429-445.

Hamilton, J. D., \& Flavin, M. (1986). On the limitations of government borrowing: A framework for empirical testing. The American Economic Review, 76(4), $808-819$.

International Monetary Fund (IMF) (2002). Assessing sustainability. Washington D.C: International Monetary Fund.

International Monetary Fund (IMF) (2013). Staff guidance note for public debt sustainability analysis in market access countries'. Washington D.C: International Monetary Fund.

International Monetary Fund (IMF) (2015). Modernizing the framework for fiscal policy and public debt sustainability analysis. Washington D.C: International Monetary Fund.

International Monetary Fund (IMF) (2018). IMF country report no 18/175'; Sri Lanka 2018 article IV consultation and fourth review under the extended arrangement under the extended arrangement under the extended fund facility - press release; staff report; and statement by the executive director for Sri Lanka. Washington D.C: International Monetary Fund.

Jha, R., \& Sharma, A. (2004). Structural breaks, unit roots, and cointegration: A further test of the sustainability of the Indian fiscal deficit. Public Finance Review, 32(2), 196-219.

Jha, R. (2010). Fiscal policies and challenges in South Asia. ASARC Working paper, no. 2010/01, viewed 27 September 2018. https://crawford.anu.edu.au/acde/ asarc/pdf/papers/2010/WP2010_01.pdf.

Jha, R., et al. (2012). Analytical approaches to assessing public debt sustainability. In Ferrarini (Ed.), Public debt sustainability in developing Asia (pp. 16-46). London and New York: Asian Development Bank and Routledge.

Jubilee Debt Campaign (2015). The new debt trap: How the response to the last global financial crisis has laid the ground for the next. Kolorco: Jubilee Debt Campaign.

Khatri, Y., Ginting, E., Athukorala, P. C., et al. (2017). Economic performance and macro management. In Athukorala (Ed.), The Sri Lanka economy, charting a new course (pp. 51-80). Philippines: Asian Development Bank.

Leeper, E. (1991). Equilibria under 'active' and 'passive' monetary and fiscal policies. Journal of Monetary Economics(27), 129-147.

Mahmood, T., Farooq-Arby, M., \& Sherazi, M. (2014). Debt sustainability: A comparative analysis of SAARC countries. Pakistan Economic and Social Reviews, 52 (1), 15-34.

Martin, G. M. (2000). US deficit sustainability: A new approach on multiple endogenous breaks. Journal of Applied Econometrics, $15,83-105$.

Mendoza, E. G., \& Ostry, J. D. (2008). International evidence on fiscal solvency: Is fiscal policy "responsible"? Journal of Monetary Economics, 55(6), 1081-1093.

Narayan, P. K. (2005). The government revenue and government expenditure nexus: Empirical evidence from nine Asian countries. Journal of Asian Economics, 15(6), 1203-1216.

Nau, R. (2018). Statistical forecasting: Notes on regression and time series analysis. Duke University. viewed 27 February 2019 , http://people.duke.edu/ rnau/ testing.htm.

Peacock, A. T., \& Wiseman, J. (1961). The growth of public expenditure in the United Kingdom. United Kingdom: Princeton University Press.

Pesaran, M. H. (2015). Time series and panel data econometrics. Oxford: Oxford University Press.

Pesaran, M. H., \& Shin, Y. (1999). An autoregressive distributed lag modelling approach to cointegration analysis. In S. Strom (Ed.), Chapter 11 in econometrics and economic theory in the 20th century the ragnar frisch centennial symposium, Cambridge: Cambridge University Press.

Pesaran, M. H., Shin, Y., \& Smith, R. J. (2001). Bounds testing approaches to the analysis of level relationship. Journal of Applied Econometrics, 16(3), 289-326.

Quintos, C. E. (1995). Sustainability of the deficit process with structural shifts. Journal of Business E' Economic Statistics, $13(4), 409-417$.

Ricci-Risquete, A., Ramajo, J., \& De Castro, F. (2016). Do Spanish fiscal regimes follow the Euro-area trends? Evidence from Markov-switching fiscal rules. Economic Modelling, 59, 484-494.

Shin, Y., Yu, B., \& Greenwood-Nimmo, M. (2014). Modelling asymmetric cointegration and dynamic multipliers in a nonlinear ARDL framework. In Sickles, \& W. Horrace (Eds.), Festschrift in honor of Peter schmidt, New York, NY: Springer.

Toda, H. Y., \& Yamamoto, T. (1995). Statistical inferences in vector autoregressions with possibly integrated processes. Journal of Econometrics, 66(1-2), 225-250. 